Editorial

\title{
Bioinorganic Chemistry of Nickel
}

\author{
Michael J. Maroney ${ }^{1, *}$ and Stefano Ciurli ${ }^{2, *(1)}$ \\ 1 Department of Chemistry and Program in Molecular and Cellular Biology, University of Massachusetts \\ Amherst, 240 Thatcher Rd. Life Sciences, Laboratory Rm N373, Amherst, MA 01003, USA \\ 2 Laboratory of Bioinorganic Chemistry, Department of Pharmacy and Biotechnology, University of Bologna, \\ Viale G. Fanin 40, I-40127 Bologna, Italy \\ * Correspondence: mmaroney@chem.umass.edu (M.J.M.); stefano.ciurli@unibo.it (S.C.)
}

Received: 11 October 2019; Accepted: 11 October 2019; Published: 30 October 2019

Following the discovery of the first specific and essential role of nickel in biology in 1975 (the dinuclear active site of the enzyme urease) [1], nickel has become a major player in bioinorganic chemistry, particularly in microorganisms, having impacts on both environmental settings and human pathologies. At least nine classes of enzymes are now known to require nickel in their active sites, including catalysis of redox $[(\mathrm{Ni}, \mathrm{Fe})$ hydrogenases, carbon monoxide dehydrogenase, methyl coenzyme $\mathrm{M}$ reductase, acetyl coenzyme A synthase, superoxide dismutase] and nonredox (glyoxalase I, acireductone dioxygenase, lactate isomerase, urease) chemistries. In addition, the dark side of nickel has been illuminated in regard to its participation in microbial pathogenesis, cancer, and immune responses. Knowledge gleaned from the investigations of inorganic chemists into the coordination and redox chemistry of this element have boosted the understanding of these biological roles of nickel in each context. In this issue, eleven contributions, including four original research articles and seven critical reviews, will update the reader on the broad spectrum of the role of nickel in biology.

The understanding of the biological role of nickel from the inorganic chemistry side is reviewed on a theoretical basis by Siegbahn et al. [2], who discuss the enzyme mechanisms, including the canonical mechanism of urease, in view of the recently reported crystal structure of the enzyme-substrate complex [3]. This chemistry is further elucidated by original contributions on the $\mathrm{pH}$ dependence of binuclear nickel peptide complexes by Keegan et al. [4].

The knowledge of proteins involved in cellular nickel trafficking (metalloregulators and metallochaperones) is summarized by Higgins in a review [5], which is complemented by a second monographic article by Nim and Wong [6], that focuses more specifically on the maturation of the nickel enzyme urease as a paradigmatic example of how cells balance nickel essentiality and toxicity. These two reviews are augmented by two original research papers on this aspect of the nickel bioinorganic chemistry field: the paper by Alfano et al. [7] is focused on CooJ, an accessory protein necessary for the maturation of the nickel-dependent enzyme carbon monoxide dehydrogenase, while the paper by Barchi and Musiani [8] describes the structure-function relationships in InrS, a nickel-dependent transcription factor from cyanobacteria.

Other reviews in this issue focus on aspects of nickel in human health, with the goal of making this literature more accessible to the bioinorganic community. The general aspects of the field are surveyed by Buxton et al. [9], while a more focused review by Maier and Benoit [10] discusses the role of nickel in microbial pathogenesis. The role of noncoding RNA in nickel-induced human cancer is discussed in a review by Zhu et al. [11], while the role of human acireductone dioxygenase in human health and its metal-dependent function are discussed in the monograph by Liu and Pochapsky [12].

The range of nickel containing systems is still expanding, as demonstrated by the original research paper by Suttisansanee and Honek, which reports a preliminary characterization of a nickel activated and mycothiol-dependent glyoxalase I from fungi [13]. 
In conclusion, we hope that these open-access contributions will serve as guiding lights for future research into the biological role of nickel. We thank the authors for their original contributions for the special issue, and we thank the reviewers for their insightful comments on each article.

\section{References}

1. Dixon, N.E.; Gazzola, C.; Blakeley, R.; Zerner, B. Jack bean urease (EC 3.5.1.5). A metalloenzyme. A simple biological role for nickel? J. Am. Chem. Soc. 1975, 97, 4131-4132. [CrossRef] [PubMed]

2. Siegbahn, P.E.M.; Chen, S.-L.; Liao, R.-Z. Theoretical Studies of Nickel-Dependent Enzymes. Inorganics 2019, 7, 95. [CrossRef]

3. Mazzei, L.; Cianci, M.; Benini, S.; Ciurli, S. The structure of the elusive urease-urea complex unveils a paradigmatic case of metallo-enzyme catalysis. Angew. Chem. Int. Ed. 2019, 131, 7493-7497. [CrossRef]

4. Keegan, B.C.; Ocampo, D.; Shearer, J. pH Dependent Reversible Formation of a Binuclear Ni2 Metal-Center within a Peptide Scaffold. Inorganics 2019, 7, 90. [CrossRef]

5. Higgins, K. Nickel Metalloregulators and Chaperones. Inorganics 2019, 7, 104. [CrossRef]

6. Nim, Y.S.; Wong, K.-B. The Maturation Pathway of Nickel Urease. Inorganics 2019, 7, 85. [CrossRef]

7. Alfano, M.; Pérard, J.; Cavazza, C. Nickel-Induced Oligomerization of the Histidine-Rich Metallochaperone CooJ from Rhodospirillum Rubrum. Inorganics 2019, 7, 84. [CrossRef]

8. Barchi, E.; Musiani, F. Molecular Modelling of the Ni(II)-Responsive Synechocystis PCC 6803 Transcriptional Regulator InrS in the Metal Bound Form. Inorganics 2019, 7, 76. [CrossRef]

9. Buxton, S.; Garman, E.; Heim, K.E.; Lyons-Darden, T.; Schlekat, C.E.; Taylor, M.D.; Oller, A.R. Concise Review of Nickel Human Health Toxicology and Ecotoxicology. Inorganics 2019, 7, 89. [CrossRef]

10. Maier, R.J.; Benoit, S.L. Role of Nickel in Microbial Pathogenesis. Inorganics 2019, 7, 80. [CrossRef]

11. Zhu, Y.; Chen, Q.Y.; Li, A.H.; Costa, M. The Role of Non-Coding RNAs Involved in Nickel-Induced Lung Carcinogenic Mechanisms. Inorganics 2019, 7, 81. [CrossRef]

12. Liu, X.; Pochapsky, T.C. Human Acireductone Dioxygenase (HsARD), Cancer and Human Health: Black Hat, White Hat or Gray? Inorganics 2019, 7, 101. [CrossRef]

13. Suttisansanee, U.; Honek, J.F. Preliminary Characterization of a Ni2+-Activated and Mycothiol-Dependent Glyoxalase I Enzyme from Streptomyces coelicolor. Inorganics 2019, 7, 99. [CrossRef]

(C) 2019 by the authors. Licensee MDPI, Basel, Switzerland. This article is an open access article distributed under the terms and conditions of the Creative Commons Attribution (CC BY) license (http://creativecommons.org/licenses/by/4.0/). 